\title{
Chapter 9 \\ Introduced Conservation Agriculture \\ Programs in Samoa: The Role of Participatory Action Research
}

\author{
Stephanie Ramona O'Connor Sulifoa and Linda J. Cox
}

\begin{abstract}
Millions of dollars have been invested in programs to encourage the adoption of sustainable farming practices associated with conservation agriculture (CA), including programs aimed at Samoan farmers. However, many smallholder farmers, including those in Samoa did not adopt the recommended practices. CA programs aimed at Samoan farmers were investigated, and participatory action research about the most recent program was conducted. Eight key informant interviews, 107 semistructured interviews, a ranking exercise involving farmers and extension officers and participant observations were completed during 2016-2017. The results provide a description of agricultural farming practices across Samoan villages; details about the role of agriculture in these villages and information on the differences between various stakeholders. Samoan farmers use CA practices and all previous CA programs prescribed practices that were not consistent with their current practices or goals. Donors, national policy makers and researchers drive top-down programs with limited term projects that focus on outputs or short-term outcomes. To alter a country's agricultural sector, particularly one dominated by smallholder farmers, it requires investment in long-term outcomes supported by a participatory action research process that ensures co-creation activities, reflexive feedback loops and cooperative buy-in approaches be given top priority.
\end{abstract}

Keywords Conservation agriculture $\cdot$ Rural areas $\cdot$ Smallholder farmers $\cdot$ Agricultural practices $\cdot$ Oceania

S. R. O. Sulifoa

Solomon Island National University, Honiara, Solomon Islands

e-mail: ramona.sulifoa@sinu.edu.sb

L. J. Cox (凶)

University of Hawaii, Honolulu, USA

e-mail: 1cox@hawaii.edu 


\subsection{The Use of Participatory Research to Ensure Smallholder Farmers' Sustainability}

Achieving the 2030 Agenda for sustainable development (UNDP 2018) hinges upon making progress in rural areas, where most of the poor and hungry live, with an agroindustrial development strategy that involves increasing the productivity and incomes of smallholder farmers and expanding the opportunities for off-farm employment in industries that are found clustered in agro-industrial sectors. Past transformations from agricultural-based economies to industry and service-based economics resulted in urbanization and higher incomes for urban consumers, which increased the demand for high-valued products such as fruit and vegetables, meat, fish and dairy. However, this brings a major array of challenges to improve the production and market conditions for small-scale farming, in addition to unprecedented natural resource constraints and global climate change. Productive and sustainable farming systems are needed in order to assure that communities across the globe can thrive in the future (FAO 2017).

Of the 570 million farms worldwide today, the $12 \%$ of farms are smallholder, producing 50\% of the human food supply (ETC Group 2009), and along with family farms accounting for $75 \%$ of the world's agricultural land (Lowder et al. 2016). Agriculturists have long been interested in adapting farm management economics originating in Europe and North American to meet the needs of small farmers, particularly those in the tropics. Work done in India (Mellor 1966) and Africa (Norman et al. 1982; Collinson 1983) examined approaches that accommodated the characteristics of smallholder farmers. The characteristics that define smallholders are:

1. They are poor and have almost no cash reserves.

2. Loans are usually unavailable or/and expensive.

3. They know they face many risks due to the uncertain environment, lack of cash and family responsibilities, which makes them risk averse.

4. Cyclical labor shortage affects farm management, and under-employment is common in rural areas.

5. Off-farm employment may be available.

6. They are rational though are not necessarily maximizing profits, due to family and community situations that affect their utility; social infrastructure that results in markets, supplies and communications being unreliable; and their social norms clearly define what is socially acceptable and what is not (Collinson 1983).

Sustainable agriculture requires more information and is more managementintensive than more conventional, large holder agriculture (Simmonds 1985). At the same time, the characteristics and situations faced of smallholders make them more vulnerable to change. In the 1960s, Francis and Hildebrand (1989) developed a participatory approach to technological improvement called farming systems research and extension (FSR/E) in response to a growing interest in fostering sustainable agriculture among smallholders. The guiding principle of FSR/E is that new technologies must conform to the environments where they will be used because farmers 
are unable to modify their environments to meet the needs of new technologies. The overall goal of FSR/E is for farmers to participate in developing and testing technologies to ensure that their criteria, rather than the narrower focus used by researchers, are used to guide decisions about efficient and effective technology development. Smallholder farmers often have a variety of economic, environmental and social goals to consider, which resulted in the holistic and interdisciplinary focus of FSR/E (Francis and Hildebrand 1989).

FSR/E applies diffusion theory developed by Rogers (1962) as the theoretical basis for this type of participatory research. Rogers (1962) concluded that the characteristics of the innovation, the social system, communication channels for reaching the end user and time devoted to extending an innovation to end users will impact the adoption of the innovation. Stakeholders including farmers, scientists and change agents responsible for outreach have differing opinions, perceptions and beliefs (Rogers 2003), and the heterotrophic nature of stakeholders may result in the use of top-down approaches (Dalton et al. 2014), rather than participatory planning approaches. The human dimensions associated with adoption decisions by farmers differ across regions (Knowler and Bradshaw 2007), also making place-based adaption necessary.

While FSR/E called for an interdisciplinary, holistic approach for many years, the FAO (2017) concluded that smallholder farmers face challenges today in identifying and adopting the technologies that can make them more productive. Agricultural growth, if broadly shared, appears to have the most positive impact on non-farm income and employment (Tsakok 2011). Economic transformations that significantly reduced a countries' poverty rate were nearly always accompanied by sustained growth in agricultural productivity (Timmer 2014). This supports the conclusion that researchers should engage with managers across all scales to reflexively explore "how things work" in the managers' organizational context to ensure that individual and collective learning occurs (Ripamonti et al. 2016). The main objective of this chapter is to investigate approaches being used to increase the adoption of CA practices by smallholder farmers in Samoa and demonstrate that a more interdisciplinary, and holistic approach is needed if agricultural growth is an overall goal in developing countries.

\subsection{Sustaining Smallholder Farmers in Samoa}

The economies in Pacific Island Countries (PICs) are becoming increasingly dependent on tourism and remittances (FAO 2012), and information about the current state of smallholder farmers in PICs is sparse. Reddy (2007) indicated that only a few sectors show promise for economic growth in PICs, where many live in rural areas and depend on agriculture for their livelihoods, while the overall population is growing rapidly. Unfortunately, agricultural efficiency in Samoa, Fiji, Papua New Guinea and Tonga did not increase from 1961 to 2004 (Reddy 2007), which indicates that the agricultural sector in these countries experiences the same challenges that 
smallholder farmers face globally. PIC farmers will be challenged to increase crop production on the limited land area with low soil fertility (Barrow 2013).

Samoa is a small PIC located south of the equator between Hawaii and New Zealand, with a total land area of $2842 \mathrm{~km}^{2}$ on the main islands of Upolu, Savaii and six smaller islands. About three-quarters of Samoa's population are involved in village agriculture, farming predominately at the subsistence and semi-subsistence level under a customary land tenure system and with household labor (Paulson and Rogers 1997; Ward and Ashcroft 1998). Wild species and traditional crops have been widely replaced by modern farming systems (Tikai and Kama 2004).

Today, Samoa's economy is dependent on foreign aid, remittances and tourism (Central Bank of Samoa 2011-2012; Connell 2015), though in the 1980s, agriculture contributed $50 \%$ of Samoa's gross domestic product (GDP). Figure 9.1 shows a decline in the contribution of agriculture to the overall GDP relative to the overall growth of the economy. The reduction in village agriculture has been attributed to a set of complex factors. For many years, various institutions have focused on soil health's contribution to the decrease in agricultural production (Mercer and Scott 1958; Blakemore 1973; Guinto et al. 2015; Anand 2016).

Taro (Colocasia esculenta) is the main staple and primary cash crop with an estimated 12,938 acres under cultivation and 17,733 farming households growing taro (Agriculture Census 2015). Taro holds cultural, monetary and dietary significance in Samoa, and the arrival of the taro leaf blight (TLB) caused by the fungus Phytophthora colocasiae in 1993 reduced production significantly. Taro yields were declining before 1993 due to intensified taro cultivation achieved by incorporating herbicide and shortening fallow periods (Ofori n.d.). TLB-resistant varieties have resulted in recent production increases with TLB-resistant taro varieties being exported to New

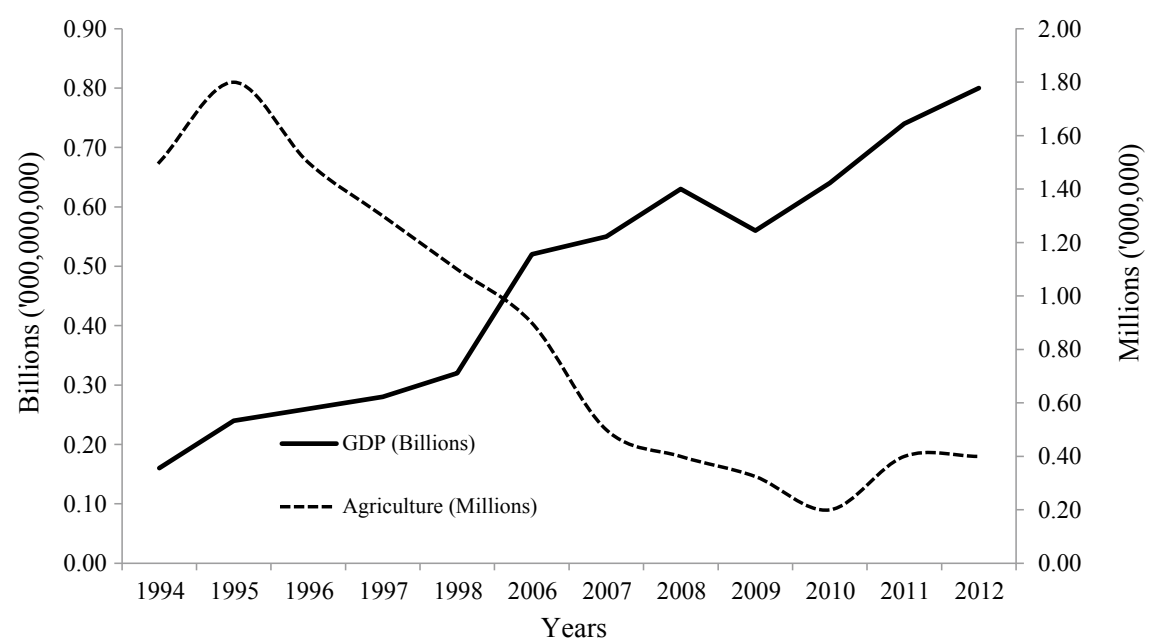

Fig. 9.1 Annual value of Samoa's total gross domestic product (GDP) and the agricultural sector in constant dollars from 1994 to 2012. Source Central Bank of Samoa 2011-2012 
Zealand starting in 2010 (Radio New Zealand October 1 2010). Local, regional and international institutions are concerned that increasing taro production will reduce soil health (ACIAR 2009; Agriculture Sector Plan 2010-2015).

\subsection{Extending Conservation Agricultural Practices to Smallholder Farmers}

Conservation agriculture (CA) is used to combat declining soil health. CA encompasses the use of three key farming practices:

1. minimal mechanical soil disturbance (i.e., zero-tillage and direct seeding);

2. maintenance of carbon-rich organic matter covering or mulch to feed the soil; and

3. rotations or sequences of crops including trees, which could include nitrogenfixing legumes (FAO 2012).

Government institutions, donor agency and non-government organizations used the logic model or theory of change to provide a framework for extending CA programs (Framst 1995; McCawley 2004) to change farmer behavior and increase sustainability (Pannell et al. 2014).

The diffusion of CA practices across agrarian societies is of interest worldwide particularly in areas where per acre productivity is declining. Although CA practices appear to offer long-term benefits, farmers, particularly those in the developing countries have not readily adopted them (Corbeels et al. 2014; Dalton et al. 2014, Pannell et al. 2014; Umar et al. 2011). Smallholder farmers in Africa were very slow to adopt CA practices because the initial setup of the system is labor intensive (Rola et al. 2009). Yield improvement from using CA practices is not immediate, and seven years may be required to realize maximum benefits, which slow the adoption for small holders (Jat et al. 2014; Paudel et al. 2014). Adoption has also been slow due to the farmers' lack of access to the appropriate equipment (Hobbs 2007). Intercropping was challenging for European farmers because they lacked the information to select compatible cash crops (Shaxson 2006). Fourteen to 20 years may be required from the time that farmers became aware of a practice until its adoption (Corbeels et al. 2014).

\subsubsection{CA Programs in Samoa}

The earliest CA work in Samoa undertaken by Reynolds (1970) and the most recent program were conducted by the Australian Center for International Agriculture Research (ACIAR) Soil Health Program from 2010 to 2015. Most of this work involved inputs from various institutions/agencies/organizations outside of Samoa 
and the Samoan government, with little input from farmers. The output was generally focused on extending scientific evidence generated to researchers and the government. Very few outreach outputs were generated, although ACIAR (2015) constructed demonstration plots, provided limited training and involved farmer opinion leaders in on-farm trials.

The ACIAR Soil Health Program identified mucuna (Mucuna pruriens) as a cover crop because Samoa's Ministry of Agriculture and Fisheries (MAF) concluded that it would reduce the use of costly herbicide for taro production by local farmers and improve soil health (T.T. personal communication December 16 2016). Mucuna was introduced into six villages on the island of Upolu and Savaii with on-farm trials in the villages of Safaatoa, Salani, Aopo and Siufaga. The trials lasted for nine months, which correspond to the taro production cycle. In the villages of Savaia, Siufaga and Sapapalii, MAF set up demonstration plots with mucuna planted as a fallow crop and mixed cropped with taro on land belonging to lead farmers and chiefs. Most of the lead farmers are semi-subsistent producers, though in the village of Savaia, they were more likely to be commercial and the village council actively involving other village farmers in the training sessions. The only training provided was on the use of mucuna. Yield data was recorded at the harvest, and farmers saw all yield differences.

\subsubsection{Evaluation of the ACIAR Program in Samoa}

From December 2016 to July 2017, in-depth interviews in the villages of Siufaga and Savaia and from Sapapalii, Aopo, Safaatoa and Salani where mucuna was also introduced were conducted with farmers that the village mayor and the high chief in the area recommended. In addition, focus groups in Siufaga, Savaia and Sapapalii were conducted, along with key informant interviews with consultants, village opinion leaders, extension officers and scientists involved with CA work in Samoa.

The interview and focus group participants indicated that tilling is not used in village level agriculture in Samoa; farmers cannot afford to own or hire a plow to till; and farmers have no knowledge of tilling and its potential negative impact on soil health. The majority of farmers do use herbicide to clear land for cultivation, though manual clearing does occur, depending on the land area that requires clearing and amount of available labor. Taro mulching was common, though vegetable mulching was not because it attracts the Giant African Snail (Achtatina fulica) and results in extensive vegetable losses. The primary crop rotation practice is fallowing between six months and two years to allow natural regrowth. Some farmers plant vegetables in their taro as a cover crop that provides food and additional income. The majority of farmers did intercrop their taro with dadap (Erythrina variegate) or Gliricidia (Gliricidia sepium) to provide nitrogen for the taro. No farmers used mucuna and the few that did try it reported that it grew too fast and was not an effective cover crop.

Village farmers in Samoa now employ all of the desirable CA practices, which participatory research such as FSR/E conducted a priori would have identified. Tikai 
and Kama (2004) concluded that understanding indigenous knowledge and engaging in more interactive technology development would produce a more efficient and costeffective path to sustainability in the agricultural sector. Top-down decision making by foreign aid organizations, researchers and high-level government officials who appear to have concluded that Samoan farmers were not using CA practices might have produced positive outcomes for the agricultural sector had a more reflexive approach been used, and indigenous knowledge was investigated.

Programs aimed at changing the behavior of farmers generally involve inputs involving extension or outreach personnel and outputs in the form of extension or outreach outputs (Rogers 1962). The process of communicating with farmers generally involves a variety of methods and differing content in order to address their concerns or lack of information or knowledge about the characteristics of the innovation, to provide feedback aimed at clarifying policies in order to further behavioral change by farmers and to facilitate on-farm research to foster farmer-to-farmer learning and farmer feedback loops to researchers and institutions in order to increase their effectiveness (Rogers 2003). Extension personnel play a key role (Vanclay 2004; Anaeto et al. 2012) in FSR/E because of the holistic link they provide between research inputs, output and behavioral change at the community level. Social scientists, who should also be included on the interdisciplinary FSR/E team, play an important role in understanding the socioeconomic, environmental and social goals of farmers (Shaner et al. 1982).

\subsection{The Value of Samoa's Extension Service in Participatory Research}

Samoa's extension service is in the MAF under the crops division, which has three main sections including research, development and advisory. In 2017, 33 extension officers were employed with 14 on the island of Upolu and 19 on the island of Savaii. MAF also has agricultural research stations located on the island of Upolu in Aleisa, Savaia and Poutasi Falealili with a main office in Nuu, while on the island of Savaii, stations are located in Salailua and Asau with the MAF headquarters in Salelologa. Tunnel houses, shade houses and demonstration plots are at each station, since in Samoa, extension officers implement village programs (Agriculture Sector Plan 2016-2020; Tuilaepa 2006).

In order to determine how participatory research might be better structured in the future, farmers from Siufaga and Savaia along with five extension officers completed a rating exercise designed to investigate their perceptions about the impact of mucuna for weed control. The ratings were analyzed using the analytical hierarchy process (AHP) developed by Saaty (2004) to estimate trade-offs in multi-criteria decision making. Figure 9.2 presents the general categories and specific components that were developed based on the interviews and focus group results about why farmers decided not to adopt mucuna. 


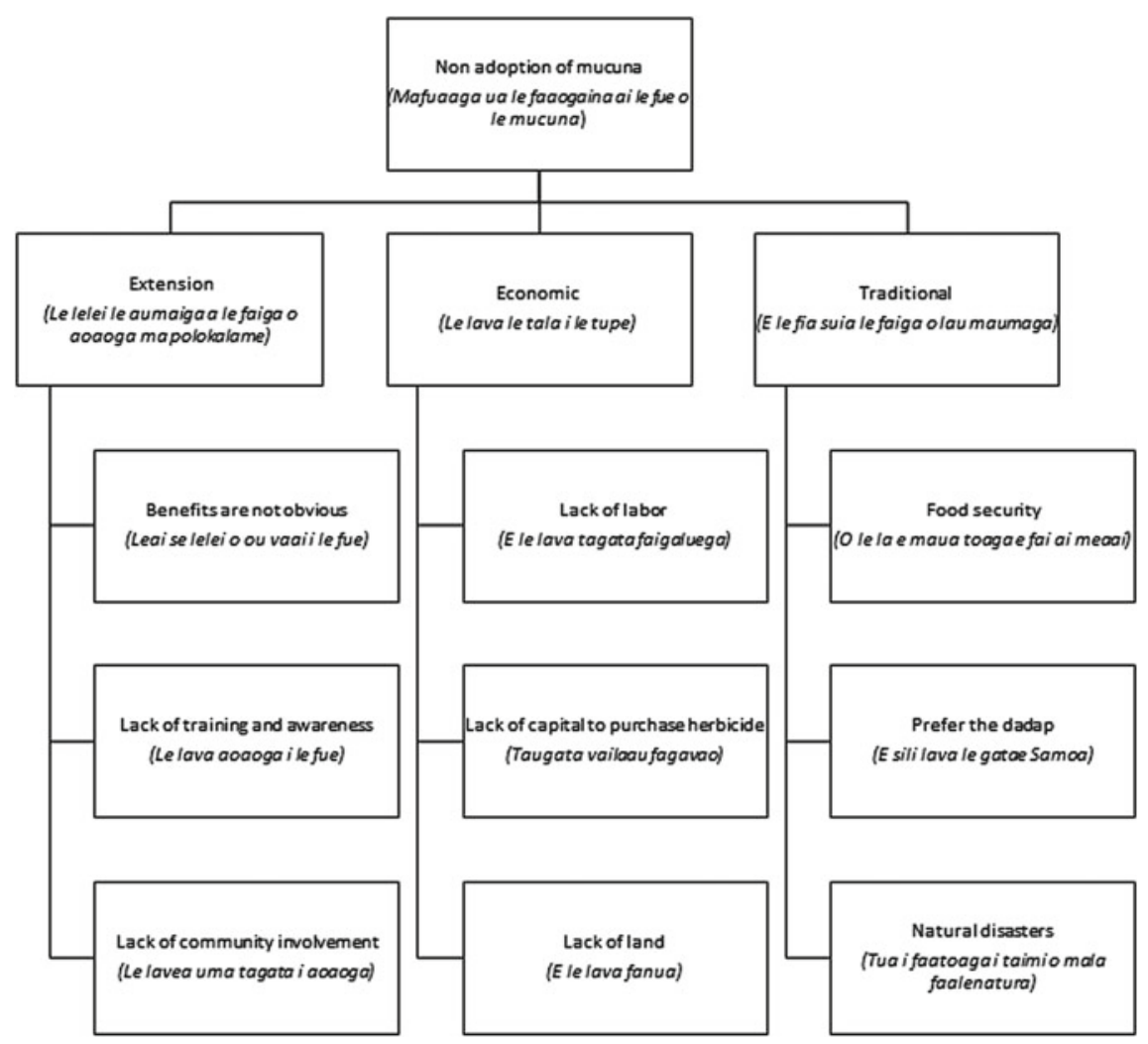

Fig. 9.2 General categories and specific components for farmers' decision not to adopt mucuna in AHP-rating exercise

The relative weights across the three general categories and each of the three specific components sets were collected using proportional piling. Proportional piling has been used as a participatory rural appraisal tool in Samoa (Le De et al. 2014). The geometric mean for each group of pairwise comparisons was entered in the SuperDecisions software using the direct entry method after normalization (Creative Decisions Foundation 2017). Spearman rank correlation, a nonparametric measure of the correlation between two ranked variables, was used to investigate differences in the relative weights between the normalized weights across various farmer groups and the extension professionals.

Table 9.1 summarizes the factors that were ranked among the top three for nonadoption of mucuna by farmers and extension officers in both villages. The ranking results across the groups were not significantly different $(p \geq 0.05)$; however, some correlation did exist between the ranks of farmers and the extension officers, i.e., Siufaga at $(r s=0.35, n=9, p=0.356)$ and Savaia, $(r s=0.57, n=9, p=0.112)$. Food security and dadap as the preferred cover crop were the top two reasons for non-adoption for famers and extension officers in Savaia. Natural disasters were also 
Table 9.1 Top three reasons for non-adoption of mucuna for farmers and extension officers in the villages of Siufaga and Savaia

\begin{tabular}{l|l|l|l|l}
\hline Rank & Siufaga farmers & Savaia farmers & $\begin{array}{l}\text { Siufaga extension } \\
\text { officers }\end{array}$ & $\begin{array}{l}\text { Savaia extension } \\
\text { officers }\end{array}$ \\
\hline First & $\begin{array}{l}\text { Community } \\
\text { involvement lacking }\end{array}$ & Food security & Dadap preferred & Dadap preferred \\
\hline Second & Herbicide cost & Dadap preferred & $\begin{array}{l}\text { Community } \\
\text { involvement lacking }\end{array}$ & Food security \\
\hline Third & Limited land area & Natural disasters & Food security & Herbicide cost \\
\hline
\end{tabular}

a concern for Savaia farmers indicating farmers' awareness of their vulnerability and the risks associated with a conversion to a new farming system that is not well understood. Since the farmers in Savaia were more likely to be commercial and the Savaia council actively involved farmers in training sessions, the factors identified by farmers are more similar to the factors identified by extension officers. Lack of community involvement appeared to be of concern only in Siufaga. In order for farmers in Siufaga to become more commercial, community involvement is likely needed since due to a lack of labor, which results in more herbicide use, and access to land would have to be addressed locally.

The extension officers and one group of farmers understood that dadap was the preferred cover crop and could have provided this information before mucuna was selected as a cover crop. Including farmers and extension officers, who also are more likely to be aware of indigenous knowledge, in the decision-making process about increasing the sustainability of Samoa's agricultural sector would have produced a more holistic program. Further discussion into how to increase community involvement, how to mitigate the risks associated with natural disaster and declining food security and the economics associated with various production inputs including herbicide would provide much insight. The socioeconomic situation in various communities could also have been investigated a priori to better understand the effect of labor shortages, high input costs and the role of farming in order to ensure that the entire effort is more successful. In situations in which commercial producers do not account for the majority of farmers, the holistic and interdisciplinary nature of FSR/E becomes a key to success and can accommodate placed-based adaptations.

\subsection{Lessons Learned}

A bottom-up, holistic approach that involves participatory research such as FSR/E is likely to require much longer planning and implementation horizons. As suggested by Ranga and Etzkowitz (2013), the relationships between the components of the innovation system are the key in resolving the flaws in previous innovation system's approaches that have a strong focus on institutions and bias toward more intensive research and development. Knowledge flows within the system that include indi- 
viduals such as extension officers and farmers, who have indigenous knowledge, will strengthen the capacity to produce integrated development strategies. Studies have shown that a combination of indigenous knowledge and science can improve development and living standards and conserve resources to ensure sustainability is achieved (Berkes et al. 2000; Tikai and Kama 2004). This knowledge has been developed through community experience over time to ensure sustainable use of resources and should not be discounted (Tikai and Kama 2004). International aid agencies, foreign, regional and national universities and national governments will be continually challenged to develop the agricultural sector in places with many smallholder farmers.

International aid agencies often speak of a "burn rate" that accounts for how fast project funds are spent to address a problem. It also implies that the agencies can determine the best solution quickly based on the opinions of the experts involved in the project. As this case study illustrates, devoting resources to the process of understanding exactly what the problem is and what solutions might be most effective could play a much larger role in making a difference than how quickly a solution suggested by experts is implemented. This result is not a novel conclusion, and the resources must be invested in the diffusion process to achieve sustainable placebased outcomes. Investigating indigenous knowledge requires a thorough placebased effort. At the same time, the actual contribution of indigenous knowledge may not be obvious immediately, and a sorting process is likely needed to maximize it. Co-investigation and co-learning that involve farmers, extension staff and other members of the community along with other experts will facilitate a process that outlines information about indigenous knowledge, the local socioeconomic system and the proposed innovation in a more usable format. For example, traditional indigenous knowledge that supports farming practices in order to help ensure long-term environmental health could be identified in order to determine the compatibility of innovations suggested by outside experts and the risks/local challenges associated with them. Understanding the local socio-ecological system and the associated indigenous knowledge would aid in the development of a communication plan and an action plan with the appropriate inputs and outputs to support diffusion.

Transdisciplinarity and reflexivity are needed to ensure that co-learning occurs across all scales. Including social scientists, extension professionals and community members on the planning team may present challenges to physical and biological researchers and high-level policymakers. Indigenous knowledge and the socioeconomic situation facing farmers require significant amounts of time to investigate and incorporate, while academics have a tendency to reward a narrow disciplinary focus (Henry 2005; Pfirman et al. 2008), and the big picture lens of policymakers challenge those involved in such efforts. Additional research into the design of a more standardized participatory process that ensures local stakeholders have been considered is needed. This will also result in more effective and meaningful policies to be developed at the community level. Participatory modeling using fuzzy-logic cognitive mapping has been shown to further social learning across individual to institutional scales (Henley-Shepard et al. 2015). Various approaches and tools to facilitate the process, such as the Mental Modeler software (Henley-Shepard et al. 2015), need to 
be investigated. Achieving genuine collaboration will require much more dedication to achieving long-term success defined across institutions and individuals at a variety of scales, from smallholder farmers, their families and their village to national policymakers, international researchers and aid agencies working across the globe.

\section{References}

Agriculture Census (2015) Report on Samoa agriculture survey. http://www.sbs.gov.ws/index.php/ new-document-library?view=download\&fileId=1845. Accessed 12 Jan 2016

Agriculture Sector Plan 2010-2015 Ministry of Agriculture and Fisheries. Volume I and Volume II. Samoa

Agriculture Sector Plan 2016-2020 Ministry of Agriculture and Fisheries. Volume I and Volume II. Samoa

Anaeto FC, Asiabaka CC, Nnadi FN, Ajaero JO, Aja OO, Ugwoke FO, Onweagba AE et al (2012) The role of extension officers and extension services in the development of agriculture in Nigeria. J Agric Res 1(6):180-185

Anand S (2016) Developing a taro (Colocasia esculenta) production system based on genotype and fallow system for economic and environmental sustainability under local conditions in Samoa. Dissertation, University of the South Pacific

Australian Center for International Agriculture Research (ACIAR) (2009) Project Proposal

Australian Center for International Agriculture Research (ACIAR) (2015) Improving soil health in support of sustainable development in the Pacific. http://aciar.gov.au/project/smcn/2009/003. Accessed 18 Dec 2015

Barrow CJ (2013) Water resources and agricultural development in the tropics. Routledge, Taylor \& Francis Group, New York

Berkes F, Colding J, Folke C (2000) Rediscovery of traditional ecological knowledge as adaptive management. Ecol Appl 10(5):1251-1262

Blakemore L (1973) Potassium status of Western Samoan soils: a note. N Z J Exp Agric 1(3):213-216

Central Bank of Samoa Reports 2011-2012. http://cbs.gov.ws/. Accessed 18 Feb 2016

Collinson MP (1983) Farm management in peasant agriculture, 2nd edn. Westview Press, Boulder Co., USA

Connell J (2015) Temporary labour migration in the Pacific. In: Khonje WH (ed) Migration and development. Perspectives from small states, Commonwealth

Corbeels M, Graaff De, Ndah TH, Penot E, Baudron F, Naudin K, Rusinamhodzi L et al (2014) Understanding the impact and adoption of conservation agriculture in Africa: a multi-scale analysis. Agric Ecosyst Environ 187:155-170. https://doi.org/10.1016/j.agee.2013.10.011

Creative Decisions Foundation (2017) SuperDecisions Software. https://www.superdecisions.com/

Dalton TJ, Yahaya I, Naab J (2014) Perceptions and performance of conservation agriculture practices in Northwestern Ghana. Agric Ecosyst Environ 187:65-71. https://doi.org/10.1016/j.agee. 2013.11.015

ETC Group (2009) Who will feed us? Questions for the food and climate crises. ETC Group Comminuque No. 102. November 2009. http://www.etcgroup.org/content/who-will-feedus. Accessed 14 June 2016

Food and Agriculture Organization of the United Nations (FAO) (2012) http://faostat.fao.org/. Accessed 20 Sept 2016

Food and Agriculture Organization of the United Nations (FAO) (2017) The state of food and agriculture: leveraging food systems for inclusive rural transformation. ISSN 0081 
Framst G (1995) Application of program logic model to agricultural technology transfer programs. Can J Program Eval 10(2):123. https://evaluationcanada.ca/secure/10-2-123.pdf. Accessed 18 June 2018

Francis C, Hildebrand PE (1989) Farming systems research/Extension and the concepts of sustainability. Agronomy \& Horticulture. Faculty Publications. 558. http://digitalcommons.unl.edu/ agronomyfacpub/558. Accessed 14 June 2018

Guinto DF, Lauga S, Dauara L, Walasi E, Autufuga D, Perera H, Seuoti D, Tauati S (2015) Soil health assessment of taro (Colocasia esculenta) farms in Samoa. University of the South Pacific, School of Agriculture and Food Technology, Alafua Campus, Samoa

Henly-Shepard S, Gray SA, Cox LJ (2015) The use of participatory modeling to promote social learning and facilitate community disaster planning. Environ Sci Policy 45:109-122. https://doi. org/10.1016/j.envsci.2014.10.004

Henry S (2005) Disciplinary hegemongy meets interdisciplinary ascendance: can interdisciplinarity survive, and if so, how? Issues Integr Stud 23:1-37

Hobbs PR (2007) Conservation agriculture: what is it and why is it important for future sustainable food production? Paper presented at the international workshop on increasing wheat yield potential, CIMMYT, Obregon, Mexico, 20-24 Mar 2006

Jat ML, Singh B, Gerard B (2014) Chapter 5-nutrient management and use efficiency in wheat systems of South Asia. Adv Agron 125:171-259. https://doi.org/10.1016/b978-0-12-800137-0. 00005-4

Knowler D, Bradshaw B (2007) Farmers' adoption of conservation agriculture: a review and synthesis of recent research. Food Policy 32(1):25-48. https://doi.org/10.1016/j.foodpol.2006.01. 003

Le De L, Gaillard JC, Friesen W, Matautia Smith F (2014) Remittances in the face of disasters: a case study of rural Samoa. Environ Dev Sustain 17:653-672. https://doi.org/10.1007/s10668014-9559-0

Lowder SK, Skoet J, Raney T (2016) The number, size, and distribution of farms, smallholder farms, and family farms worldwide. World Dev 87:16-29. https://doi.org/10.1016/j.worlddev.2015.10. 041 (Accessed 18 June 2018)

McCawley PF (2004) The logic model for program planning and evaluation. https://www.d.umn. edu/ kgilbert/educ5165-731/Readings/The\%20Logic\%20Model.pdf. Accessed 18 April 2016

Mellor JW (1966) Agricultural growth—structures and patterns. http://ageconsearch.umn.edu/ bitstream/182449/2/IAAE-CONF-142.pdf. Accessed 18 June 2018

Mercer J, Scott P (1958) Changing village agriculture in Western Samoa. Royal Geogr Soc, London

Norman DW, Simmons EB, Hays HM (1982) Farming systems in the Nigerian Savanna. Research and strategies for development. Westview Press, Boulder CO, USA

Pannell DJ, Llewellyn RS, Corbeels M (2014) The farm-level economics of conservation agriculture for resource-poor farmers. Agric Ecosyst Environ 187:52-64. https://doi.org/10.1016/j.agee. 2013.10.014

Paudel B, Radovich JKT, Chan-Halbrendt C, Crow S, Tamang TT, Halbrendt J, Thapa K (2014) Effect of conservation agriculture on maize-based farming systems in the mid-hills of Nepal. Proc Eng 78:327-336. https://doi.org/10.1016/j.proeng.2014.07.074

Paulson DD, Rogers S (1997) Maintaining subsistence security in Western Samoa. Geoforum 28(2):173-187. https://doi.org/10.1016/S0016-7185(97)00005-5

Pfirman S, Martin P, Berry L, Fletcher M, Hempel M, Hombach SR, Hornbach D, Morehouse B (2008) Interdisciplinary hiring, tenure and promotion: guidance for individuals and institutions. Council of Environmental Deans and Directors. http://www.uvm.edu/ tri/pdf/NCSEInterdisciplinaryHiring.pdf. Accessed 14 June 2018

Radio New Zealand, 1st October 2010. First Samoan taro export in a decade heads to New Zealand. Retrieved from: https://www.radionz.co.nz/international/pacific-news/192859/first-samoan-taroexport-in-a-decade-heads-to-new-zealand. Accessed 18 April 2018 
Ranga M, Etzkowitz H (2013) Triple Helix systems: an analytical framework for innovation policy and practice in the knowledge society. Ind High Educ 27(4):237-262. https://doi.org/10.5367/ ihe.2013.0165

Reddy M (2007) Enhancing the agricultural sector in Pacific Island economies. Pacific Econ Bull 22-3:48-62

Reynolds SG (1970) Manual of introductory soil science and simple soil analysis methods. University of the South Pacific, Alafua Campus, Samoa

Ripamonti S, Galuppo L, Gorli M, Scaratti G, Cunliffe AL (2016) Pushing action research toward reflexive practice. J Manage Inq 25(1):55-68. https://doi.org/10.1177/1056492615584972

Rogers E (1962) Diffusion of innovations. Free Press of Glencoe, New York

Rogers E (2003) Diffusion of innovations, 5th edn. Free Press, New York, London

Rola AC, Sajise AJU, Harder DS, Alpuerto JMM (2009) Soil conservation decisions and upland corn productivity: a Philippine case study. Asian J Agric Dev 2(6):19

Saaty T (2004) Decision making - the analytic hierarchy and network processes (AHP/ANP). J Syst Sci Syst Eng 13(1):1-35

Shaner WW, Philipp PF, Schmehl WR (1982) Farming systems research and development guidelines for developing countries. Westview Press, Boulder CO, USA

Shaxson TF (2006) Re-thinking the conservation of carbon, water, and soil: a different perspective. Agron Sustain Dev 26(1):9-19. https://doi.org/10.1051/agro:2005054

Simmonds NW (1985) Farming systems research: a review World Bank technical paper number 43, WTP43 August 1985 Page 15. http://documents.worldbank.org/curated/en/ $111831468740665537 /$ pdf/multi-page.pdf. Accessed 14 June 2018

Tikai P, Kama A (2004) A study of indigenous knowledge and its role to sustainable agriculture in Samoa. Solomon Island National University National working paper. University of the South Pacific, Alafua Campus, Samoa

Timmer CP (2014) Managing structural transformation: a political economy approach. WIDER Annual Lecture 18

Tsakok I (2011) Success in agricultural transformation: what it means and what makes it happen. Cambridge University Press, Cambridge, USA

Tuilaepa FS (2006) A participatory model of rural poverty in Samoa. Dissertation, Lincoln University

Umar B, Aune J, Johnsen F (2011) Options for improving smallholder conservation agriculture in Zambia. J Agric Sci 3(3):50-62. https://doi.org/10.5539/jas.v3n3p50

United Nations Development Programme (UNDP) (2018) Sustainable development goals. Retrieved from http://www.undp.org/content/undp/en/home/sustainable-development-goals.html

Vanclay F (2004) Social principles for agricultural extension to assist in the promotion of natural resource management. Aust J Exp Agric 44(3):213-222. https://doi.org/10.1071/EA02139

Ward R, Ashcroft P (1998) Samoa: mapping the diversity. Institute of Pacific Studies, University of the South Pacific; National University of Samoa, Suva, Apia

Open Access This chapter is licensed under the terms of the Creative Commons Attribution 4.0 International License (http://creativecommons.org/licenses/by/4.0/), which permits use, sharing, adaptation, distribution and reproduction in any medium or format, as long as you give appropriate credit to the original author(s) and the source, provide a link to the Creative Commons licence and indicate if changes were made.

The images or other third party material in this chapter are included in the chapter's Creative Commons licence, unless indicated otherwise in a credit line to the material. If material is not included in the chapter's Creative Commons licence and your intended use is not permitted by statutory regulation or exceeds the permitted use, you will need to obtain permission directly from the copyright holder.

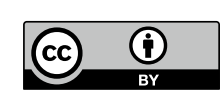

